\title{
PSEUDOMEMBRANOUS ENTEROCOLITIS WITH JEJUNAL PERFORATION ASSOCIATED WITH CL. WELCHII INFECTION
}

\author{
By W. BrumfitT, M.B., M.R.C.P., and E. A. Wright, M.D., M.R.C.P. \\ From the Wright-Fleming Institute and Department of Pathology, St. Mary's Hospital Medical School, W.2
}

Acute inflammatory ulceration of the small and large intestines may occur after abdominal operations (Finney, I893; Finsterer, 1914; Penner and Bernheim, 1939; Williams and Pullan, 1953). Recently emphasis has been placed on the danger of this condition occurring after antibiotic therapy (Jackson et al., 195I; Gardner, 1953). These authors report antibiotic-resistant staphylococcal enterocolitis both in surgical and non-surgical patients after antibiotic therapy. Herrell et al. (1953) report three non-fatal cases in which no antibiotics were given. Other cases have been reported where no causative organism was discovered (Dearing and Heilman, 1953; Pettet et al., I954).

Williams (1926-27) drew attention to the possible significance of toxin production in the human intestine by $\mathrm{Cl}$. Welchii. Howie et al. (1953) found Cl. Welchii, type $\mathrm{A}$, in the gastric aspirate of 12 of the I 5 post-operative partial gastrectomy cases examined and one of these developed diarrhoea. $\mathrm{Cl}$. Welchii infection causing sloughing inflammation of the jejunum, ileum and colon has been described by Zeissler and Rassfeld-Sternberg (1949) and Hain (1949). The causal organism was heat-resistant and was subsequently designated type F by Oakley (1949). These cases of ' enteritis necroticans' which occurred in Germany were frequently fatal and were due to infection of food, although not all those who took the food were affected.

We describe below a case of pseudomembranous enterocolitis with perforation possibly due to $\mathrm{Cl}$. Welchii, type A. There was no association with an operation or antibiotic therapy.

\section{Case History}

S.T., a male railway porter, aged 60 years, attended the out-patient department on 8.2.56, complaining of shortness of breath on exertion and swelling of the ankles, and of passing loose fatty stools twice daily during the last three weeks. Ten years previously he had complained of lassitude and a feeling of cold. These symptoms had been relieved by 2 gr. thyroid daily and this treatment was continued until 3.2.56, when, because of the present illness, digoxin, $0.25 \mathrm{mg}$. daily, was started and the thyroid stopped.

On examination the patient was found to have oedema of the ankles and sacrum, and the liver was just palpable. The pulse was 90 per minute, B.P. I IO/60, and temperature $98^{\circ} \mathrm{F}$. He was given Lugol's iodine, 5 minims t.d.s., and digoxin, 0.25 mg. t.d.s., and sent home to bed. On 15.2 .56 at 8.30 a.m. there was an abrupt onset of severe colicky lower abdominal pain not relieved by defaecation. When admitted to hospital eight hours later he was found to be markedly dehydrated, the skin was dry and scaly and the extremities were cold and blue. The abdomen was grossly distended, soft and not tender and was tympanitic in all areas. An X-ray showed distension of the large bowel in the region of the splenic flexure and descending colon. Bowel sounds were present and there was ballooning of the rectum. He was treated with intravenous fluids and morphine.

On 16.2 .56 he became disorientated and his blood pressure continued to fall: on 17.2 .56 coma supervened and he died at I.I 5 a.m.

\section{Post-mortem Examination}

The body was examined 12 hours after death. The skin was dry, scaly and also showed bluish-red striae. The heart (320 g.) and vascular system showed no relevant abnormality. Apart from small collections of clear pleural fluid (right, $300 \mathrm{ml}$.; left, $150 \mathrm{ml}$.) and early terminal bronchopneumonia the respiratory system was normal. The alimentary system was normal until $6 \mathrm{~cm}$. distal to the pylorus, where ulceration was found, and this extended throughout the small intestine. It was most severe in the jejunum and extended with diminishing severity to the ileum. The jejunum (Fig. I) was perforated $80 \mathrm{~cm}$. from the duodenojejunal junction (orifice $4 \times 6 \mathrm{~mm}$., $2 \mathrm{~cm}$. from the mesenteric border). There was a small circumferential area of peritoneal reaction around the perforation which was closed by adjacent adherent 


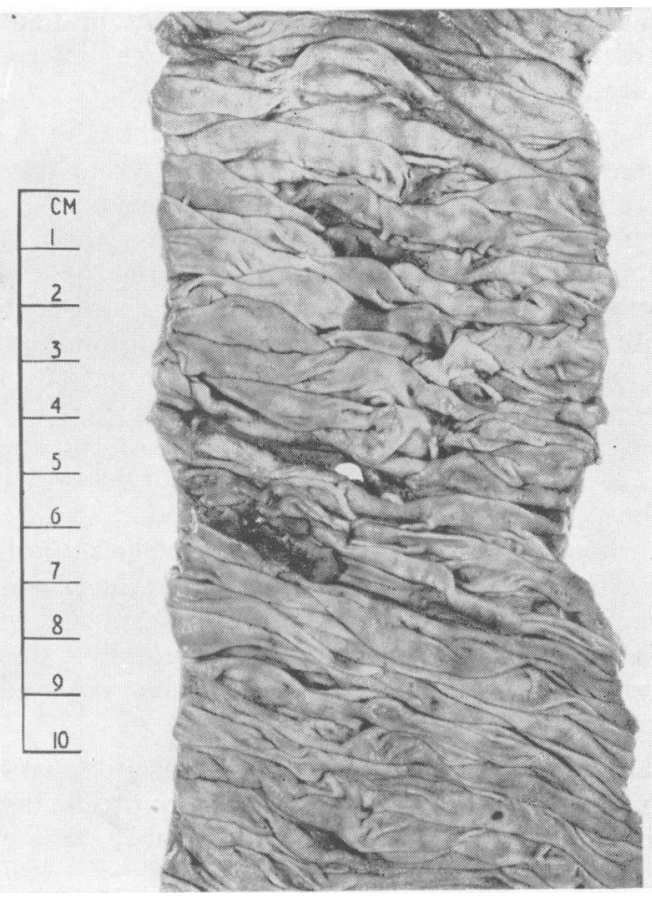

FIG. 1.-Photograph of jejunum showing perforation and ulceration.

coils of bowel. Most of the ulcers were approximately $\mathrm{I} \mathrm{cm}$. in diameter and oval in shape, lying transversely. Most of them were covered with a thick layer of fibrino-purulent exudate (Fig. 2) in the form of a flat disc that overhung the edge of the ulcer, giving a flattened mushroom-like appearance. The exudate could be scraped away to reveal a floor of varying depth; some ulcers had sharp edges, but others had indeterminate edges. The large bowel showed two ulcers in the transverse colon which were similar to those in the small gut. The mucosa of the large bowel was acutely inflamed, particularly over the crests of the rugae, which also contained numerous submucosal petechiae. The rectum was normal. The peritoneal cavity contained more than $1,000 \mathrm{ml}$. of thick greenish-yellow purulent fluid. The peritoneum was everywhere acutely inflamed and soft fibrinopurulent exudate adhered to the points of contact between the coils of the intestine. The mesenteries were inflamed, congested and oedematous. The liver $(2,230$ g.) was enlarged and its cut surface showed an accentuated pattern. The gall-bladder, bile ducts and pancreas were normal. The spleen (I2 g.) was small and fibrotic. The thyroid gland (8 g.) consisted mainly of fibrous tissue. The right adrenal gland contained a haemorrhage in its lower pole. The left adrenal and the pituitary gland were

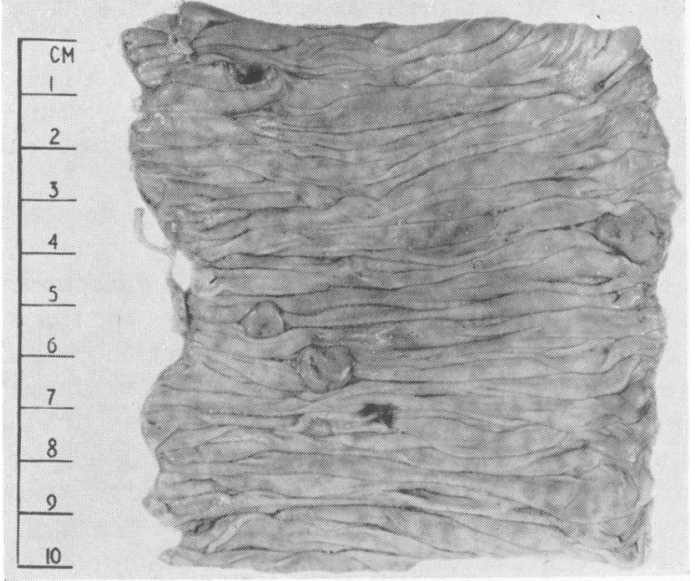

Fig. 2.- Jejunum showing three mushroom-like lesions and a number of ulcers.

normal. The left kidney contained an old healed cortical infarct. Other organs were normal.

\section{Microscopic Examination}

The intestinal ulcers were of varying depth, but most of them showed loss of epithelium with adjacent necrosis and acute inflammatory change. The exudates consisted of masses of fibrin containing numerous acute inflammatory cells. With Gram's stain gram-positive organisms could be found in the tissues and membrane. The liver showed a severe degree of fatty change that was mostly distributed periportally. The thyroid was atrophied. The myocardium showed moderate diffuse fibrous replacement. Sections of the lungs showed slight oedema and early bronchopneumonia. A small haemorrhage was present in the medulla and cortex of the right adrenal. Sections of the spleen, pituitary, kidney and skin showed no relevant abnormalities.

\section{Bacteriological Investigation}

Films prepared from the membrane and from the jejunal contents showed enormous numbers of gram-positive pleomorphic bacilli with truncated ends. Culture of lesions and of jejunal contents after 24 hours' anaerobic culture at $37^{\circ} \mathrm{C}$. on blood agar produced a good growth of discrete colonies surrounded by beta haemolysis. The organism was gram-positive, non-sporing and nonmotile. Growth in Robertson's cooked meat medium turned the meat pink, but no digestion was noted after i4 days. Loeffler's slope was not digested. Aerobic culture produced a few colonies of $E$. coli. Selective cultures were made for staphylococci and fungi, but none were grown. 
None of the common enteric pathogens were isolated.

The organism isolated anaerobically produced acid and gas in glucose, maltose, lactose and sucrose, but not in salicin or mannitol. Growth in litmus milk gave acid, gas and clot with stormy fermentation. Lecithinase production was demonstrated by the Nagler plate reaction. The organism was killed by heating to $100^{\circ} \mathrm{C}$. for three minutes. Inoculation of $0.1 \mathrm{ml}$. broth culture into the thigh of a guinea-pig caused death in 24 hours, the postmortem appearances being characteristic of gas gangrene, whilst intra-duodenal instillation of the same broth culture $(0.5 \mathrm{ml}$.) was without effect on another guinea-pig. These findings showed the organism to be $\mathrm{Cl}$. Welchii. It was later examined by Professor Prévot, of the Institut Pasteur, who identified it as $\mathrm{Cl}$. Welchii, type A.

\section{Discussion}

Several points of interest arise: first, Kleckner et al. (1952) drew attention to the importance of cardiac disease in the aetiology of pseudomembranous enterocolitis, it being present in five of their I4 cases and was present in our patient. Secondly, type F Cl. Welchii is known to cause necrotic enteritis in man (Zeissler and RassfeldSternberg, 1949) and the finding of an almost pure growth of $\mathrm{Cl}$. Welchii, type A, in the small intestine of our case may have a similar significance. Cregan and Hayward (1953), investigating the normal flora of the small intestine in living subjects, found mainly gram-positive organisms of the variety found in the mouth and assumed that this was the origin of the flora of the small intestine. The special liability of enterocolitis to occur after abdominal operation or following therapy with broad-spectrum antibiotics may be related to the difficulty which bacteria have in establishing themselves in the small intestine. Bennetts (1932) found it difficult to produce experimental enterotoxaemia in sheep (due to $\mathrm{Cl}$. Welchii, type D) unless he first gave belladonna and morphine to inhibit intestinal movements.

In our case it is difficult to exclude the possibility that $\mathrm{Cl}$. Welchii, present in the gut before death, multiplied rapidly after death and invaded the small intestine. However, in view of the known association of feebly haemolytic strains of type A Cl. Welchii with food poisoning (Hobbs et al., 1953) and the relationship of the severe type $\mathrm{F} \mathrm{Cl}$. Welchii infection to enteritis necroticans, the relationship of the $\mathrm{Cl}$. Welchii to the lesion must be considered. Prévot has seen two similar cases to ours in which he regarded $C l$. Welchii, type $\mathrm{A}$, as the aetiological agent (personal communication, 1956). No help in diagnosis was gained from the histology and Pettet et al. (1954) found no dif- ference in the various types of pseudomembranous enterocolitis either macroscopically or microscopically.

The clinical findings can be accounted for by the morbid anatomical lesions. The thyroid was severely atrophied, but whether this was a primary lesion or whether in some measure the result of prolonged thyroid administration cannot be determined. The signs of heart failure accord with the diffuse fibrosis of the myocardium, although no aetiology can be given. The sudden onset of abdominal pain would agree well with the perforation of the bowel and the reaction in the peritoneal cavity and the exudate around the orifice of the perforation could have occurred within 12 to 24 hours. The liver lesions showed periportal fatty change. This is usually ascribed to the effects of bacterial intoxication and might be expected in cases of generalized peritonitis where endotoxins of gram-negative bacteria would be released (Cameron et al., 1940).

Perforation in association with pseudomembranous enteritis is uncommon and by producing an intestinal ileus it added considerably to the difficulties of diagnosis of this case.

\section{Summary}

A fatal case of pseudomembranous enterocolitis with perforation of the jejunum is described.

The significance of the presence of $\mathrm{Cl}$. Welchii, type $\mathrm{A}$, in the lesions is discussed.

\section{BIBLIOGRAPHY}

BENNETTS, H. W. (1932), Bull. Coun. sci. industr. Res. Australia, No. 57.

CAMERON, G. R., DELAFIELD, M. E., and WILSON, J. (1940), भ. Path. Bact., 51, 223.

CREGAN, J., and HAYWARD, N. J. (1953), Brit. med. f., i, 1356. DEARING, W. H., and HEILMAN, F. R. (1953), Proc. Mayo Clin., 28, 121.

FINNEY, J. T. M. (1893), Bull. fohns Hopk. Hosp., 4, 53.

FINSTERER, H. (1914), Dtsch. Z. Chir., 128, 5 I 4.

GARDNER, D. L. (1953), Lancet, ii, 1236.

HAIN, E. (1949), Brit. med. f., i, 27 I.

HERRELL, W. E., NICHOLS, D. R., and MARTIN, W. J. (1953), F. Amer. med. Ass., 152, 1601 .

HOBBS, B. C. SMITH, M. E., OAKLEY, C. L., WARRACK, G. H., and CRUIKSHANK, J. C. (1953), f. Hyg. (Camb.), 5I, 75.

HOWIE, J. W., DUNCAN, I. B. R., and MACKIE, L. M. (1953), Lancet, ii, 1018.

JACKSON, G. C., HAIGHT, T. H., KASS, E. H., WOMACK, C. R., GOCKE, T. M., and FINLAND, M.' (1951), Ann. intern. Med., 35, 1175.

KLECKNER, M. S., BARGEN, J. A., and BAGGENSTROSSE, A. H. (1952), Gastroenterology, $21,212$.

OAKLEY, C. L. (1949), Brit. med. F., i, 269.

PENNER, A., and BERNHEIM, A. I. (1939), Arch. Path. (Chicago), 27,966 .

PETTET, J. D., BAGGENSTROSS, A. H., DEARING, W. H., and JUDD, E. S. (1954), Surg. Gynec. Obstet., 98, 546.

PREVOT (1956), personal communication.

WILLIAMS, B. W. (1926-27), Brit. F. Surg., 14, 295.

WILliAMS, M. R., and PULLAN, J. M. (1953), Lancet, ii, 1013.

ZEISSLER, J., and RASSFELD-STERNBERG, L. (1949), Brit. med. $\mathcal{F}$., $i, 2 \leqslant 7$. 